Journal of Social and Development Sciences (ISSN 2221-1152)

Vol. 7, No. 2, pp. 28-31, June 2016

\title{
Study of Community Participation in the Process of Villages Infrastructure Development on Program PNPM Mandiri in Jayapura Regency
}

\author{
Flora Yvonne de Quelyoe, Elsyan Reinette Marlissa, Sarlota Ratang \\ University of Cenderawasih Jayapura Papua, Indonesia \\ floradeq_06@yahoo.co.id, elsyan_marlissa@yahoo.com
}

\begin{abstract}
Community participation in each process of public policy making is an important issue as the mirror of principle of democracy in a country. It would be very precise when participation of community later became one of the principles that should be implemented by the government in an effort to realize good governance. The importance of participation and form of participation given a supporting factor for the success of the government program. The aim of Road Infrastructure development program is to increase local community welfare so they are able to access a wide range economy, social and politic activities. For example, in economic activity, the local producer can easily carry and sell their product to the local market when compared to the previous moment when road was damaged, especially during the rainy seasons. Therefore it is necessary participation of community to engage in solving the road infrastructure problem in their respective villages and districts. This research is located in Jayapura Regency, and using explanatory research with qualitative approach. The Techniques of data collection on this study is using questionnaire, distributed to 80 respondents. The result of this research shows that community participation community in the planning, implementation and evaluation is very good. Community participation on implementation phase of National Program of Community Empowerment (PNPM Mandiri) is really determined by the level community involvement in the planning stages. The important reasons related to community participation are: a) the engagement of community, either directly or indirectly, are able to create feel of belongings to all public asset that has been built with high cost. b) Through community participation, they know about the limitation of government resources (funds, manpower). c) Involvement of local society in those development stages could be a control tools to supervise all development financing in the level of village, district, and regency as well.
\end{abstract}

Keyword: Community participation, Villages Development, Community, Empowerment

\section{Introduction}

National development is development effort is implemented gradually and based on priority scale covering all of Nation and country life (Supriady, 2005). To achieve national goals, stated in the Preamble of the Constitution Act of 1945, namely to protect all people and land of Indonesia, realize the general welfare educating the nation, participate in the establishment of world order based on freedom, lasting peace and social justice. Autonomy as a form of decentralization of government essentially intended to meet the interests of the nation as a whole (Sumarto, 2003). This policy is an attempt to get closer to the goals of governance to realize the ideals of a justice and prosperous society. The existence of Law No 32 of 2004 on local government, directed to accelerate equitable distribution of development results so as to improve the welfare of the people through using their potential, in particular the development of the village (Achmadu, 1990). In the context of rural development, participatory become an important issue, not only being a target of rural development, but also because the most likely to receive the impact of development program is village community itself (Adisasminta, 2006; Hidayat, 2005; Sumarto, 2003). Seems that, Indonesian Government have convinced that participation of community in the development planning is a major prerequisite for the success of development in Indonesia. The willingness of Indonesian government to understand the importance of community participation in development planning is a step forward (Sumarto, 2003). Despite the government's desire to support participation, but there are still many challenges in the 
field. However, to encourage people to participate in the development process is a problem that still needs to be solved. The utilization of local potential, especially in rural development will be a valuable activity in order to achieved society welfare (Kartasasmita, 1996).

\section{Literature Review}

Community Participation: Participation means that an activity in order to evoke feelings and participate or taking a part in the activities of an organization (Hidayat, 2005). Participation is essentially to unify the consideration of the interest of the organization and individual satisfaction, but it is also seen as a technique of the relationship of employment. Therefore, participation in the spotlight as an important position within the scope of employment relationships (Sumarto, 2003). Herein, Participation is defined as an engagement or involvement of the person's mental and emotional situations that encourage groups to contribute their assets or belongings in order to reach organizational goals and should be responsible for the participation. So, participation is a form of attitude or behavior that supports the existence of a program (Sumarto, 2003). Initially, the behavior itself is individual's perception which is used to manage environments. The activity carried out by an individual is a perception that can be defined as a process of learning that connects past experiences with the reality today. Then, it will be compared with the alternative way to be taken, which will eventually emerge as a particular action of the people and manifested in form of participation (Hidayat, 2005). Community participation is the psychological events that include mental and emotional involvement. In this case the community is expected to observe, choose, interpret and understand a various types of information received and then will be implemented in the form of action. In addition, the community participation in this context is the engagement totally of individuals (physical, thoughts, material and feelings) as well as their willingness to support the success of an activity (Supriady, 2005). The community, who is actively involved in mutual cooperation, deliberations, and meeting, could be considered as a form of community participation. Community participation is also able to be increased by giving a stimulus in the form of grants, coaching, guidance and supervisions (Rukmana, 1993).

Participation is also being importance issue in development context, because public participation give a contribution to the effort of funds utilizing efficiently and transparency. It is because all financing of development activity comes from public funds that must be supervised by the public directly or indirectly (Sumarto, 2003). Participation of society allows decision making which are based on priority needs and public capabilities. It could result in policy design, program, and finance which more realistic and encourage the people to donate their resources such as money, manpower and ideas as well for successful development. Generally, participation has the purpose to create a shared vision, building plans, brainstorm, settings of priorities or make a choice, aspiration and collect information (Siagian, 2005). Based on several opinions above, it can be concluded that public participation is really effective when people are involve in all development process, starting from planning, implementation and evaluation until the stage of receiving the result of development. Participation which has been elaborated before is able to support the process of implementing development program.

Development: Development is an effort to achieve growth and changes which is implemented consciously, and carried out by a nation, state and government towards modernity in order to develop the nation (Rukmana, 1993). In addition, development is process of change towards through the effort undertaken in planned manner. Concept of development is an effort to make changes towards better conditions (Suryono, 2001; Syafiie, 1999). The approach in development activity which focused on the community should be changed to the community-centered approach. It means that the development is focused on the community as a central figure (Yuwono, 2001). Along with the development of the concept and implementation of development in several countries, then there is changing of development paradigm, starting from peoplecentered strategy until community empowerment strategy as has being mentioned as an alternative of community development (Department Pekerjaan Umum, 2009). It is at least related to new direction of development, such as alignment on society and community empowerment. Infrastructure refers to the physical systems that provide transportation, irrigation, drainage, buildings and other public facilities are 
required to meet basic human needs in the social and economic sphere. Infrastructure is a major supporter of functions of economic system in people daily lives. Infrastructure system can be defined as facilities or basic structures, installation equipment are built and serves as a social and economic system (Andi, 2005; Kodoatie, 2005).

\section{Methodology}

This research is explanatory that aims to test the hypothesis that there is relationships between participation in planning, implementation and monitoring in PNPM Mandiri. The research variables are consisting of 4 (four) variables namely: planning, implementation and monitoring as independent variables and participation as dependent variable. Number of respondent is 80 people which is getting proportionally random sampling. The measure instrument is questionnaire which contains about 40 questions with Likert scale. Data analysis tools used is multiple linear regression analysis with SPSS software version 20.

\section{Results and Discussion}

The characteristics of educational background of the respondents are Senior High School (35\%) and under graduate $(31 \%)$. Most of the society in urban areas is already having good education, mainly primary and secondary education. The characteristic of respondents by age showed that most respondent (68\%) are above 50 years old, whereas the respondents on lower than 50 years old is about $32 \%$. Characteristic respondents are disperse to various type of occupation, as such private officials (29\%), housewives (22\%), entrepreneurs $(13 \%)$, government official $(13 \%)$, trader $(11 \%)$, unskilled laborers $(4 \%)$, retired $(3 \%)$, professional (3\%) dan farmer (2\%). The results of regression analysis are able to describe the impact of 3 (three) independent variables (planning, implementation and supervision) to level of participation on PNPM Mandiri as being elaborated on Table 1.

Table 1: Result of Regression Analysis

\begin{tabular}{llcllll}
\hline Model & & $\begin{array}{c}\text { Unstandardized } \\
\text { Coefficients }\end{array}$ & $\begin{array}{l}\text { Standardized } \\
\text { Coefficients }\end{array}$ & \\
Std. & Error & Beta & T & P \\
\hline 1 & (Constant) & 5.924 & 2.917 & & 2.031 & 0.046 \\
& X1. Planning & 0.240 & 0.073 & 0.320 & 3.299 & 0.001 \\
& X2.Implementati & 0.231 & 0.086 & 0.294 & 2.683 & 0.009 \\
& X3. Supervision & 0.224 & 0.084 & 0.262 & 2.660 & 0.010 \\
\hline $\mathrm{R}^{2}=0.526$, Adj- $\mathrm{R}^{2}=0.508 ; \mathrm{F}=28.144(\mathrm{p}=0.000)$ & & &
\end{tabular}

Result of Regression Analysis explain that those three independent variables simultaneously influenced significantly to participation of the community $(52,6 \%)$. The coefficients of regression has positive, which means that when most community are engaged in each stages of planning, implementation and supervision, so the participation on PNPM Mandiri is going increase. Test result partially of each independent variables is also conclude that those independent variables are influenced significantly to the level of participation $(p<0,05)$. Based on standardized coefficient value (beta), planning get highest value $(0,320)$ compared to other independent variables. The analysis result give an interpretation that participation of the society is determined by the ability and commitment of PNPM Mandiri facilitator to invite all society in order to involve totally on stage of planning, implementation and supervision. The initial step of development is planning or decision making, is starting with identified all communities needs until development program, because they really understand about their needs than government or outsider people. Therefore, the local village society must be involved on the stage planning through local community forum (Andi, 2009). It is not merely on the planning step, however, it should be done on the second (implementation), and the third 
stage (supervision) as well. So that the program is really matching to community needs (basic and secondary). There are 3 main important reasons related to community participation which are: 1) the engagement of community, either directly or indirectly, are able to create feel of belongings to all public asset that has been built with high cost. They would take care all asset, such as drainage pipe, village office; public toilet, etc. 2) through community participation, they know about the limitation of the resources (funds, manpower). So they are going to understand and give respect to the government, when their program are postponed to next period program; 3) Involvement of local society in those development stages, could be a control tools to supervise all development financing in the level of village, district, and regency as well,

\section{Conclusion}

High awareness of local community to participate in all stage of development program, because they are willing to be an actor in the village development activities. Then, they are expected to changes their live and improves their welfare, individually, family or ethnic group. On participation side, seems that there are several of community participation in PNPM Mandiri in Jayapura Regency. Starting from the role of government (village, local, province) and all stakeholders. The importance things in the whole stages is transparency in providing information about the program, and funding as well. Transparency, accountability and communication are very important because those factors could be an obstacle in implementation of development program, especially in case of community participation. The importance reasons related to community participation which are: a) the engagement of community, either directly or indirectly, are able to create feel of belongings to all public asset that has been built with high cost. b) Through community participation, they know about the limitation of the resources (funds, manpower). c) Involvement of local society in those development stages, could be a control tools to supervise all development financing in the level of village, district, and regency as well.

\section{References}

Achmadu. (1990). Rural Development Focused, Jakarta, Prisma.

Adisasmita, R. (2006). Building Participatory Village, Graha Ilmu, Yogyakarta.

Andi, A. (2005). Construction Project Management. UNTAD Press-Palu.

Andi, A. (2009). The Quality of Rural Infrastructure Development with the Involvement of Local Communities. Jurnal SMARTEK, 4(2). Fakultas Teknik, Universitas Tadulako.

Department Pekerjaan Umum. (2009). Technical Policy of Rural and Urban infrastructure development based on community empowerment.

Hidayat, W. (2005). Participatory Development. Yogyakarta : Penerbit YPAPI.

Kartasasmita, G. (1996). Combining growth and Equity, Lidesindo, Jakarta.

Kodoatie, R. (2005). Introduction of Infrastructure Management, Pustaka Pelajar, Yogyakarta.

Mansor, M., Said, I. \& Mohamad, I. (2012). Experiential Contacts with Green Infrastructure's Diversity and Well-being of Urban Community. Procedia - Social and Behavioral Sciences, 49, 257-267.

Rukmana, D. W. N. (1993). Management of Rural Infrastructure Development. Jakarta : LP3S.

Siagian, S. P. (2005). Development Administration, Dimensions Concept and Its Strategy. Jakarta: Bumi Aksara.

Soekanto, S. (2005). Sociology an Introduction, PT. Raja Grafindo Persada, Jakarta

Sumarto, H. S. (2003). Inovation, Participation and Good Governance. Jakarta : Yayasan Obor Indonesia.

Supriady, D. R. (2005). Regional Development Planning. Jakarta : SUN.

Suryono, A. (2001). Theory and Development Issues. Jakarta: UN Press.

Syafiie, I. K. (1999). Theory and Development Issues, Rineka Cipta, Jakarta.

Yuwono, T. (2001). Regional Autonomy Management: Building an Area Based on a New Paradigm, Clogapps Diponogoro University, Semarang. 